\title{
Oral manifestations of lymphoma: a systematic review
}

\author{
Taísa Domingues Bernardes Silva', Camila Belo Tavares Ferreira², Gustavo Boehmer Leite ${ }^{3}$, José Roberto de Menezes Pontes ${ }^{4}$ \\ and Héliton S Antunes ${ }^{5}$
}

${ }^{1}$ Instituto Nacional de Câncer (INCA), Rio de Janeiro, Brazil

${ }^{2}$ Library Section, Instituto Nacional de Câncer (INCA), Rio de Janeiro, Brazil

${ }^{3}$ Private practice

${ }^{4}$ Dentistry Section, Instituto Nacional de Câncer (INCA), Rio de Janeiro, Brazil

${ }^{5}$ Clinical Research Division, Instituto Nacional de Câncer (INCA), Rua André Cavalcante, n 37, 2 andar, Rio de Janeiro, RJ CEP20231-050, Brazil

Correspondence to: Taísa Domingues Bernardes Silva. Email: taisabernardes@gmail.com

\section{Abstract}

Lymphoma is a malignant disease with two forms: Hodgkin's lymphoma (HL) and non-Hodgkin's lymphoma (NHL). Non-Hodgkin's lymphoma is diagnosed in extranodal sites in $40 \%$ of cases, and the head and neck region is the second most affected, with an incidence of $11-33 \%$, while HL has a very low incidence in extranodal sites (1-4\%). The aim of this study was to identify the oral manifestations of lymphoma through a systematic literature review, which we conducted using the PubMed, Lilacs, Embase, and Cochrane Library databases. We found 1456 articles, from which we selected 73. Among the intraoral findings, the most frequent were ulcerations, pain, swelling, and tooth mobility, while the extraoral findings included facial asymmetry and cervical, submandibular, and submental lymphadenopathy. Among the few studies reporting imaging findings, the most cited lesions included hypodense lesions with diffuse boundaries, bone resorptions, and tooth displacements. The publications reviewed highlight gaps in the areas of early detection, diagnosis, and proper treatment.

Keywords: lymphoma, oral cavity, dental care, oral manifestations

Published: $17 / 08 / 2016$

Received: 15/03/2016

ecancer 2016, 10:665 DOI: 10.3332/ecancer.2016.665

Copyright: (c) the authors; licensee ecancermedicalscience. This is an Open Access article distributed under the terms of the Creative Commons Attribution License (http://creativecommons.org/licenses/by/3.0), which permits unrestricted use, distribution, and reproduction in any medium, provided the original work is properly cited. 


\section{Introduction}

Lymphoma is a heterogenous malignant disease of the lymphatic system, characterised by a proliferation of lymphoid cells or their precursors [1]. Lymphomas present different behaviours and degrees of aggressiveness and can be divided into two large groups: Hodgkin's lymphoma (HL) and non-Hodgkin's Lymphoma (NHL). Hodgkin's lymphoma occurs mainly in the lymph nodes (>90\%) [2] and only $1-4 \%$ of the cases involve extranodal areas [3-4], appearing as a nodal disease with predilection for neck and mediastinal nodes [2, 5-7]. Hodgkin's lymphoma is diagnosed when the histopathological examination shows the presence of Reed-Sternberg cells [8] which are binucleate cells with a generally abundant cytoplasm and two large nucleoli (one in each core) that appear like 'owl eyes'. Hodgkin's lymphoma can be further classified as classic HL or lymphocyte-predominant HL with respective incidences of $95 \%$ and $5 \%$. The former has a bimodal age distribution with an early peak in young people (ages 20-24) and another peak in elderly patients aged 80-84, while the latter can occur at any age, but most often occurs in individuals between 30 and 50 years of age [2]. The disease's nodal evolution is contiguous, and its clinical evolution is slow and predictable which favours therapeutic protocols [3]. In extranodal site, NHL represents $40 \%$ of all lymphomas [2]. Over 20 different subtypes have been classified according to the type of lymphoid cell and its behaviour. Nodal evolution proceeds randomly with an unpredictable clinical outcome [3]. Morphological, immunophenotypic, and cytogenetic characteristics are essential for the classification of each subtype of NHL. The gastrointestinal tract is the most common site of extranodal disease, occurring in over $50 \%$ of patients, followed by head and neck which varies from $11-33 \%$ [9], where the most frequent age group is over 50 years old.

Lymphomas are the third most common cancer worldwide and constitute $3 \%$ of malignant tumours. They make up $2.2 \%$ of all malignancies of the head and neck and are the second most frequent in that region surpassed only by epithelial malignancies [10]. The global estimate of new yearly cases of NHL is 217,643 for males and 168,098 for females while that of HL is 38,520 for males and 24,430 for females [11].

Patients with acquired immunodeficiency syndrome (AIDS) have a higher risk to develop Non-Hodgkin's lymphoma [12], about 100-200 times the risk of the general population [13]. This malignancy has been reported as the second most common in this group of patients, Kaposi's sarcoma being the most common [13-14], and the extranodal presentation occuring more commonly in 70-80\% of the cases [12]. In comparison with the general population, AIDS-related lymphomas have a rapid progression, bad response to the treatment, high relapse rates and overall poor prognosis [13 and 15].

The most recent and widely used classification is that of the World Health Organisation (WHO). It is based on the Revised European-American Lymphoma (REAL) classification and primarily subdivides lymphomas based on cellular origin: B cell lymphomas, T cell lymphomas, natural killer lymphomas, and Hodgkin's lymphoma [16-18]. Furthermore, the WHO classification includes new immunogenetic, morphological, and molecular characteristics [19]. The most widely used lymphoma staging classification system is the Ann Arbor classification [20-22], which is based on the number of regions of the involved lymph nodes, and the presence of extranodal disease, disease above and below the diaphragm, and systemic symptoms [2].

The treatment of lymphoma in the head and neck is complex because of the numerous variables involved and depends on clinical staging [23]. The different treatment modalities include: 1) radiotherapy, which plays a limited role in the primary treatment of NHL and has been successful only when gingival lesions are present; 2) chemotherapy, with or without radiation, which is the modality most often used in most lymphomas and is generally recommended in disseminated disease stages III or IV; 3) growth factors that limit myelosuppression; and 4) bone marrow transplant and monoclonal antibodies which act against the surface antigens of affected cells [24].

Oral cavity lymphomas represent the third most common malignancy in the oral cavity, surpassed by squamous cell carcinoma and malignancies of the salivary glands. Lymphomas in the oral cavity are rare; only $3 \%$ of all lymphomas in the general population and $4 \%$ on patients with AIDS [25].

The manifestations of oral lymphomas are often difficult to diagnose because they present clinical features that mimic other diseases such as periodontal disease, osteomyelitis, and other malignancies [26]. This may delay the correct treatment thereby worsening the prognosis.

Thus, the aim of this systematic review was to identify the oral manifestations of lymphoma reported in scientific publications in order to assist health professionals in the initial diagnosis, prognosis, and treatment. 


\section{Materials and methods}

\section{Search strategy}

We searched for articles published until 31 December 2015 in the following databases: Literatura Latino-Americana e do Caribe emCiências da Saúde (LILACS), Medline (via PubMed), Embase, and the Cochrane library (Cochrane reviews and Cochrane trials). Our search strategy involved combining terms associated with the inclusion and exclusion criteria as well as the guiding question in the different databases. We also used the Boolean operator not together with terms for treatment options in order to reduce the number of articles involving lymphoma treatments. We also restricted the search to studies performed with humans (Figure 1).

\section{Study selection criteria}

Studies eligible for inclusion were: i) case reports, literature reviews, retrospective studies, or prospective studies that addressed the oral manifestations of lymphoma published until 31 December 2015; and ii) publications in English, Spanish, or Portuguese. Studies focusing solely on lymphoma therapies and outcomes, without information on the oral manifestations were excluded.

We found 153 publications in LILACS, 249 in Cochrane reviews, 179 in Cochrane trials, 447 in Embase, and 428 in PubMed.

We then conducted a second selection after reading the titles and abstracts. This selection left 150 references of which 94 remained for the following round. We then read the full text of the 94 studies and 21 of those were excluded for not meeting the established criteria. Thus, 73 studies made up the final selection as illustrated in the flowchart following the PRISMA model [27] shown in Figure 2.

Figure 1. Strategy protocols.

\begin{tabular}{|c|c|c|}
\hline Databases & Sensitive search strategy & Results \\
\hline Pubmed & $\begin{array}{l}\text { ((Oral manifestations [mh] or oral [ti] or mouth [ti] or 'oral manifestations' [ti]) and } \\
\text { (lymphoma [ti] or Lymphoma [mh]) and (humans [mesh])) not (('lymphoma/drug } \\
\text { therapy' [mesh] or 'lymphoma/therapy' [mesh]) and (humans [mesh])) }\end{array}$ & 428 \\
\hline Lilacs & Oral and (linfoma or lymphoma) & 153 \\
\hline Cochrane library & $\begin{array}{l}\text { \#1 MeSH descriptor: [oral manifestations] explode all trees } \\
\text { \#2 oral or mouth or 'oral manifestations' } \\
\text { \#3 \#1 or \#2 } \\
\text { \#4 MeSH descriptor: [signs and symptoms] explode all trees } \\
\text { \#5 symptom or manifest* or clinical }{ }^{*} \\
\# 6 \text { \#4 or \#5 } \\
\# 7 \text { Lymphoma } \\
\text { \#8 MeSH descriptor: [lymphoma] explode all trees } \\
\# 9 \text { \#7 or \#8 } \\
\# 10 \text { \#9 and \#6 and \#3 } \\
\# 11 \text { MeSH descriptor: [lymphoma] explode all trees and with qualifiers: [Drug } \\
\text { therapy - DT, Therapy - TH] } \\
\text { \#12 \#10 not \#11 }\end{array}$ & $\begin{array}{l}\text { COCHRANE REVIEWS = } 249 \\
\text { COCHARNE TRIALS }=179\end{array}$ \\
\hline Embase & $\begin{array}{l}\text { \#13. 'mouth'/exp or mouth and ('disease'/exp or disease) or 'oral } \\
\text { manifestations':ab,ti or oral:ti or mouth:ti and ('lymphoma'/exp or lymphoma or } \\
\text { lymphoma:ab,ti) not ('letter'/it or 'editorial'/lit or ('animal'/exp or 'animal':ab,ti not } \\
\text { ('animal'/exp or 'animal':ab,ti and ('human'/exp or 'human':ab,ti)))) not ('drug'/ } \\
\text { exp or drug and ('therapy'/exp or therapy) or drug*:ab,ti or chemother*:ab,ti) and } \\
\text { clinic':ab,ti and ([article]/lim or [review]/lim) and ([english]/lim or [portuguese]/ } \text { lim or [spanish]/lim) and [abstracts]/lim and [embase]/lim and [humans]/lim not } \\
\text { (genet*:ab,ti or gene*:ab,ti or protein*:ab,ti or antigen*:ab,ti }\end{array}$ & 447 \\
\hline
\end{tabular}




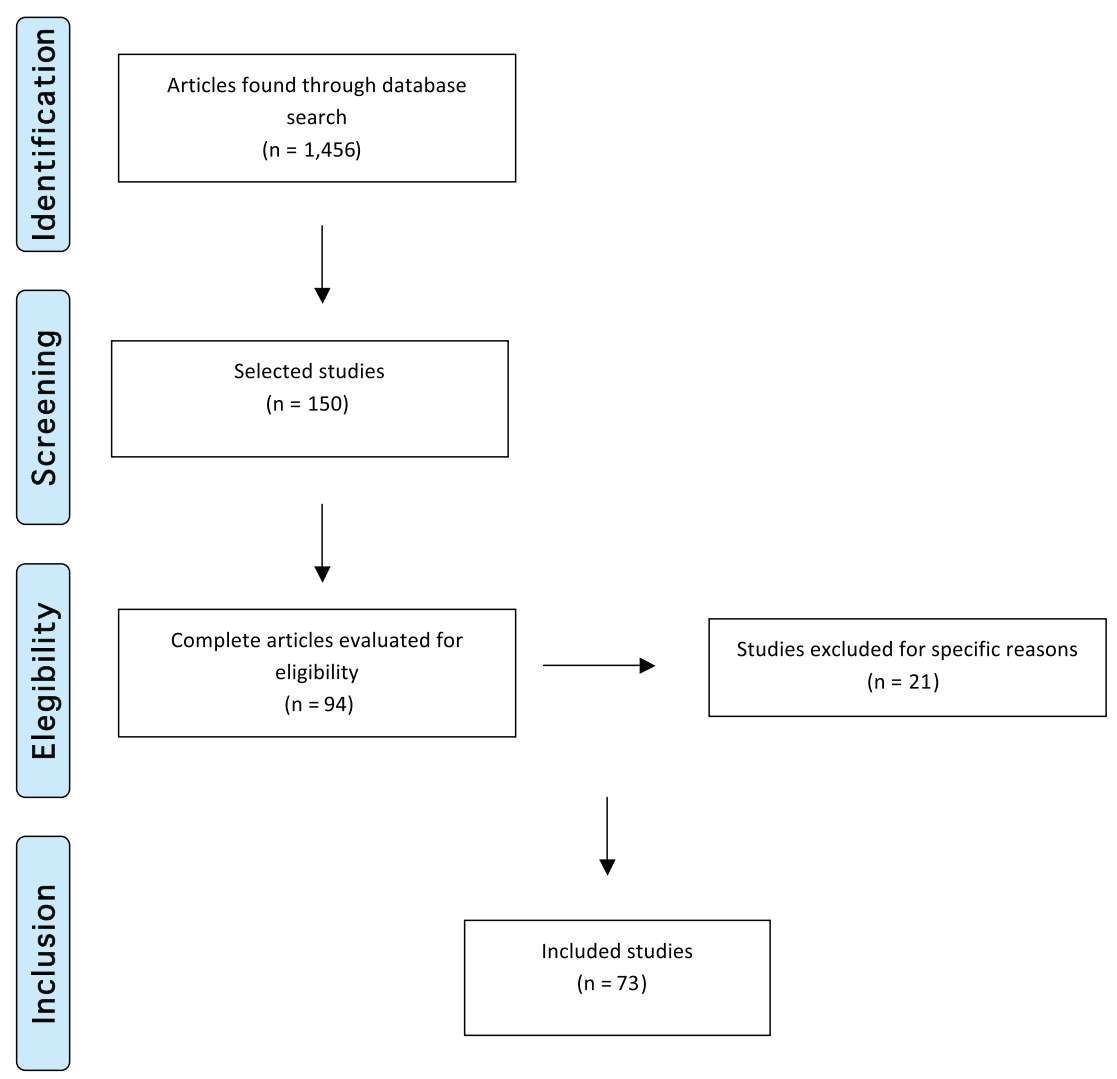

Figure 2. Flowchart illustrating study selection based on the PRISMA model (Adapted from Moher D et al (2009) The PRISMA Group, 2009). Preferred Reporting Items for Systematic Reviews and Meta-Analyses: The PRISMA Statement PLoS Med 6(6) e1000097. DOI: 10.1371/journal. pmed1000097)

\section{Data extraction}

To extract data from the selected studies, we elaborated a document analysis chart containing the following variables: publication title, study authors, publication year, place of publication, and study design. For clinical case studies, the following variables were analysed: gender, age, type of lymphoma, lymphoma location, intraoral and extraoral examinations, and imaging studies.

\section{Results}

The first article published on this topic was a case report from 1970. Of the 73 articles included in this systematic review, 51 were clinical cases $(69.9 \%), 16$ were retrospective studies $(21.9 \%)$, four were narrative reviews $(5.5 \%)$, and two was a systematic review $(2.7 \%)$, including a total of 978 reviewed cases. Of these, 361 cases $(36,9 \%)$ were reported in a single cohort study conducted in Canada by Epstein et al [10] and 87 cases (8.9\%) were also reported in a single study, by Horiuchi et al [64] in the United States. These studies were responsible for reporting almost half of all cases.

In terms of lymphoma types, diffuse large B-cell non-Hodgkin's lymphoma (DLBCL) was the most frequent, with 288 cases, followed by 99 cases of small cell non-Hodgkin's lymphoma, and 79 cases of Burkitt's lymphoma. All other types of lymphoma are listed in Table 1. 
Table 1. Published case reports and retrospective studies.

\begin{tabular}{|c|c|c|c|c|c|}
\hline Author - Year & N of cases & Gender & Age & Diagnosis & Study type \\
\hline FORMAN - 1970 & 1 & M & 25 & $\mathrm{HL}$ & Case Report \\
\hline HARMAN - 1971 & 1 & M & 57 & MF & Case Report \\
\hline LASKARIS - 1978 & 1 & $\mathrm{~F}$ & 65 & MF & Case Report \\
\hline WRIGHT - 1981 & 1 & M & 60 & MF & Case Report \\
\hline HORIUCHI - 1982 & 87 & $46 \mathrm{M} ; 41 \mathrm{~F}$ & 46 (2 to 82$)$ & HL: 31; ML: 28; DLPD: 20; BL: 05; DWDLL: 03 & Retrospective Study \\
\hline COHEN - 1984 & 1 & $\mathrm{~F}$ & 34 & $\mathrm{HL}$ & Case Report \\
\hline BARKER - 1984 & 7 & $5 \mathrm{M} ; 2 \mathrm{~F}$ & $52(16$ to 84$)$ & LL: 02; LLI: 02; ML: 01; FL: 01; RCC: 01 & Retrospective Study \\
\hline EISENBUD - 1985 & 6 & $4 \mathrm{M} ; 2 \mathrm{~F}$ & (3 to 16$)$ & BL: 05; DLBCL: 01 & Case Report \\
\hline EVANS - 1986 & 1 & $\mathrm{~F}$ & 52 & MF & Case Report \\
\hline KAUGARS - 1989 & 1 & M & 34 & DLBCL & Case Report \\
\hline SODERHOLM - 1989 & 17 & $7 \mathrm{M} ; 10 \mathrm{~F}$ & $52(13$ to 90$)$ & N/A: 14; BL: 03 & Retrospective Study \\
\hline SPATAFORE - 1989 & 1 & M & 46 & ML & Case Report \\
\hline GROOT - 1990 & 3 & $3 \mathrm{M}$ & $44 ; 35 ; 42$ & BL:01; DML: 02 & Case Report \\
\hline DODD - 1992 & 3 & $3 \mathrm{M}$ & $43 ; 40 ; 46$ & DLBCL: 03 & Case Report \\
\hline SIROIS - 1993 & 8 & $5 \mathrm{M} ; 3 \mathrm{~F}$ & 62 (49 to 75$)$ & TCL: 08 & Case Report \\
\hline SCULLY - 1993 & 1 & M & 15 & $\mathrm{TCL}$ & Case Report \\
\hline PILUSO - 1994 & 2 & $2 \mathrm{M}$ & $26 ; 37$ & IL: 02 & Case Report \\
\hline ROSENBERG - 1996 & 2 & $1 \mathrm{~F} ; 1 \mathrm{M}$ & $75 ; 61$ & TCL: 02 & Case Report \\
\hline SHINDOH - 1997 & 52 & $29 \mathrm{M} ; 23 \mathrm{~F}$ & 54 (5 to 86$)$ & $\begin{array}{l}\text { DLL: 23; ML: 05; SNC: 06; FL: 03; MFL: 02; } \\
\text { BL: 01; IL: 08; NC: 02; DSC: } 02\end{array}$ & Retrospective Study \\
\hline NITTAYANANTA - 1998 & 2 & $2 \mathrm{M}$ & $26 ; 25$ & BL: 02 & Case Report \\
\hline SAVARRIO - 1999 & 1 & $\mathrm{M}$ & 77 & ALCL & Case Report \\
\hline MORET - 1999 & 1 & $\mathrm{M}$ & 81 & LNC & Case Report \\
\hline RICHARDS - 2000 & 2 & $2 \mathrm{M}$ & $49 ; 61$ & DLBCL: 01; TCL: 01 & Case Report \\
\hline DE LA FUENTE - 2000 & 2 & $2 \mathrm{~F}$ & $66 ; 45$ & MF: 02 & Case Report \\
\hline EPSTEIN - 2001 & 361 & $200 \mathrm{M} ; 161 \mathrm{~F}$ & 63 (2 to 96$)$ & $\begin{array}{c}\text { DLBCL: 137; SCL: 99; PL: 23; IL: 11; BL: 06; } \\
\text { HL: 03; NC: } 82\end{array}$ & Retrospective Study \\
\hline JAEHNE - 2001 & 26 & $6 \mathrm{M} ; 20 \mathrm{~F}$ & 66 (48 to 74$)$ & NHL: 26 & Retrospective Study \\
\hline CONTRERAS - 2001 & 4 & $2 \mathrm{~F} ; 2 \mathrm{M}$ & $56 ; 73 ; 34 ; 55$ & DLBCL; 04 & Case Report \\
\hline NALLI - 2003 & 12 & $9 \mathrm{M} ; 3 \mathrm{~F}$ & 45 ( 7 to 82$)$ & N/A: 12 & Retrospective Study \\
\hline WAIN - 2003 & 1 & $\mathrm{M}$ & 9 & MF & Case Report \\
\hline VAN DER WAAL - 2004 & 40 & $24 \mathrm{M} ; 16 \mathrm{~F}$ & 46 (3 to 88$)$ & DLBCL: 40 & Retrospective Study \\
\hline RADHAKRISHNAN - 2005 & 1 & $\mathrm{M}$ & 7 & PBL & Case Report \\
\hline ALBUQUERQUE - 2005 & 1 & $\mathrm{~F}$ & 30 & $\mathrm{TCL}$ & Case Report \\
\hline KOJIMA - 2006 & 1 & $\mathrm{~F}$ & 64 & MALT & Case Report \\
\hline OTMANI - 2007 & 37 & $31 \mathrm{M} ; 6 \mathrm{~F}$ & $7(2$ to 15$)$ & BL: 37 & Retrospective Study \\
\hline JHAM - 2007 & 1 & M & 62 & DLBCL & Case Report \\
\hline FARIAS - 2008 & 1 & $\mathrm{M}$ & 54 & DLBCL & Case Report \\
\hline FREITAS - 2008 & 1 & $\mathrm{M}$ & 7 & $\mathrm{BL}$ & Case Report \\
\hline
\end{tabular}


Table 1. Published case reports and retrospective studies. (continued)

\begin{tabular}{|c|c|c|c|c|c|}
\hline Author - Year & $\mathrm{N}$ of cases & Gender & Age & Diagnosis & Study type \\
\hline KEMP - 2008 & 40 & $19 \mathrm{M} ; 21 \mathrm{~F}$ & 71 (35 to 89$)$ & $\begin{array}{l}\text { DLBCL: 23; FL: 06; ENMZL: 05; PL/MM:03; } \\
\text { SLL/CLL: 02; TCL: } 01\end{array}$ & Retrospective Study \\
\hline KESZLER - 2008 & 40 & $23 \mathrm{M} ; 17 \mathrm{~F}$ & 49 (3 to 90$)$ & $\begin{array}{l}\text { DLBCL: 09; PL: 09; LCPB: 05; BL:06; PBL: 05; } \\
\text { FL: 05; LHG: } 01\end{array}$ & Retrospective Study \\
\hline DE-MISA - 2008 & 1 & $\mathrm{M}$ & 72 & LyP & Case Report \\
\hline SANTOS - 2009 & 1 & $\mathrm{M}$ & 22 & DLBCL & Case Report \\
\hline VILLA - 2009 & 1 & $\mathrm{M}$ & 57 & $\mathrm{TCL}$ & Case Report \\
\hline BEGON - 2010 & 1 & $\mathrm{~F}$ & 34 & $\mathrm{TCL}$ & Case Report \\
\hline BORTOLUZZI - 2010 & 1 & $\mathrm{M}$ & 73 & DLBCL & Case Report \\
\hline RAO - 2010 & 2 & $2 \mathrm{M}$ & $65 ; 70$ & PBL: 02 & Case Report \\
\hline PEREIRA - 2010 & 2 & $2 \mathrm{M}$ & $4 ; 24$ & BL:02 & Case Report \\
\hline BULUT - 2011 & 1 & $\mathrm{M}$ & 74 & DLBCL & Case Report \\
\hline INCHINGOLO - 2011 & 1 & $\mathrm{M}$ & 73 & $\mathrm{NHL}$ & Case Report \\
\hline BOMBECCARI - 2011 & 1 & $\mathrm{M}$ & 11 & MALT & Case Report \\
\hline $\mathrm{CHI}-2012$ & 1 & $\mathrm{~F}$ & 40 & DLBCL & Case Report \\
\hline CHICARELLI - 2012 & 1 & $\mathrm{M}$ & 45 & $\mathrm{MCL}$ & Case Report \\
\hline KIKUCHI - 2012 & 1 & $\mathrm{~F}$ & 61 & $\mathrm{BL}$ & Case Report \\
\hline TRIANTAFILLIDOU - 2012 & 58 & $32 \mathrm{M} ; 26 \mathrm{~F}$ & 45 (8 to 81$)$ & $\begin{array}{l}\text { DLBCL: 19; SLL/CLL: 10; MALT: 21; MCL: 04; } \\
\text { FL: 02; BL: 01; B-ALL: } 01\end{array}$ & Retrospective Study \\
\hline FORTUNA - 2012 & 1 & $\mathrm{~F}$ & 39 & PBL & Case Report \\
\hline GABALI 2013 & 1 & $\mathrm{M}$ & 11 & MALT & Case Report \\
\hline FERREIRA 2013 & 1 & $\mathrm{~F}$ & 38 & $\mathrm{TCL}$ & Case Report \\
\hline PINISETTI -2013 & 1 & $\mathrm{~F}$ & 38 & $\mathrm{BL}$ & Case Report \\
\hline SCHWETHA - 2014 & 1 & $\mathrm{~F}$ & 62 & $\mathrm{NHL}$ & Case Report \\
\hline MEDEL - 2014 & 1 & $\mathrm{M}$ & 52 & PBL & Case Report \\
\hline COZZOLINO - 2014 & 14 & $4 \mathrm{M} ; 10 \mathrm{~F}$ & $68(45$ to 84$)$ & DLBCL: 8; MALT: 4; FL 2 & Retrospective Study \\
\hline RAMANATHAN - 2014 & 42 & $25 \mathrm{M} ; 17 \mathrm{~F}$ & $48(2$ to 40$)$ & BCL: 17; TCL: 10; BL: 6; NHL: 6; DLBCL: 3 & Retrospective Study \\
\hline OWOSHO - 2014 & 26 & $13 \mathrm{M} ; 13 \mathrm{~F}$ & (33 to 88$)$ & DLBCL: 20; MCL: 1; DLBCL/BL :5 & Retrospective Study \\
\hline CORTI - 2015 & 1 & $\mathrm{M}$ & 39 & PBL & Case Report \\
\hline CUESTAS -2015 & 1 & $\mathrm{M}$ & 7 & $\mathrm{BL}$ & Case Report \\
\hline SAMOON - 2015 & 1 & $\mathrm{~F}$ & 30 & PBL & Case Report \\
\hline PHILIPONE - 2015 & 47 & $22 \mathrm{M} ; 25 \mathrm{~F}$ & 70.8 (36 to 94$)$ & $\begin{array}{l}\text { DLBCL: 13; SLL/CLL:8; FL:6; MALT: 5; PL:5; } \\
\text { PBL: 3; MCL: 2; TCL: 2; NHL: 2; BCL: } 1\end{array}$ & Retrospective Study \\
\hline
\end{tabular}

$\mathrm{HL}=$ Hodgkin's Lymphoma; MF = Mycosis Fungoides; ML = Malignant lymphoma; DPDL = diffuse poorly differentiated lymphocytic lymphoma;

$\mathrm{BL}$ = Burkitt's lymphoma; DWDLL = diffuse well-differentiated lymphocytic lymphoma; $\mathrm{LBL}=$ lymphoblastic lymphoma; $\mathrm{RCC}=$ reticular Cell Carcinoma; $\mathrm{LL}$ = lymphoblastic lymphosarcoma; $\mathrm{LLI}=$ lymphocytic lymphosarcoma; $F L$ = follicular lymphoma; $\mathrm{DLL}=$ diffuse lymphoblastic lymphoma;

DLBCL = diffuse large B-cell lymphoma; N/A = not available; $\mathrm{DML}$ = diffuse mixed lymphoma; $\mathrm{TCL}$ = T-cell lymphoma; IL = immunoblastic lymphoma; $\mathrm{DLCL}=$ diffuse large-cell lymphoma; SNC = small non-cleaved cell malignant lymphoma; NC = Not Classifiable; MFL = mixed malignant follicular lymphoma; DSC = diffuse malignant small-cleaved-cell lymphoma; ALCL = anaplastic large-cell lymphoma; LNC = large non-cleaved cell non-Hodgkin's lymphoma; $\mathrm{NHL}$ = non-Hodgkin's lymphoma; $\mathrm{SCL}=$ small cell lymphoma; $\mathrm{PBL}$ = plasmablastic lymphoma; $\mathrm{PL}=$ plasmacytoma; $\mathrm{MALT}=$ extranodal marginal zone lymphoma of mucosa-associated lymphoid tissue; ENMZL = extranodal marginal zone lymphoma; PL/MM = plasmacytoma/multiple myeloma; SLL/CLL = small lymphocytic lymphoma / chronic lymphocytic leukemia; LHG = high-grade lymphoma B; LyP = lymphomatoid papulosis; $\mathrm{B}-\mathrm{ALL}=$ acute lymphoblastic leukemia $\mathrm{B} ; \mathrm{MCL}=$ mantle-cell lymphoma; DLBCL/BL: B-cell lymphoma unclassifiable with features intermediate between DLBCL and BL; BCL = B-cell lymphoma. 
The main clinical manifestations reported in the articles included in this systematic review were swelling in 218 cases, pain in 1289 cases, and paresthesia in 62 cases (Figure 3). As for location, the tonsils were the most affected in the head and neck region, appearing in 119 cases, followed by salivary glands with 109 cases, while the maxilla was the most affected bone region, with 90 cases reported (Figure 4). It is important to note that some articles did not describe the specific lesion sites and instead used broad terms such as 'Waldeyer's ring' and 'oral cavity', which may not give a completely accurate idea of the most frequent location. Of the 163 cases with imaging results, the most frequent feature was the radiolucent image, meaning absence of bone or bone erosion, with 141 cases (Figure 5 ). As for gender, there were 546 males versus 432 females. The youngest patient was diagnosed with NHL at 2 years of age and the oldest at 96 .

Of the clinical cases studied, $40.52 \%$ were initially misdiagnosed as a different pathology and were treated as such, delaying proper treatment, and allowing the progression of lymphoma. Most treatments were extractions, periodontal treatments, and abscess treatments. Many of the retrospective studies did not report the initial diagnosis of individual cases, precluding that evaluation.

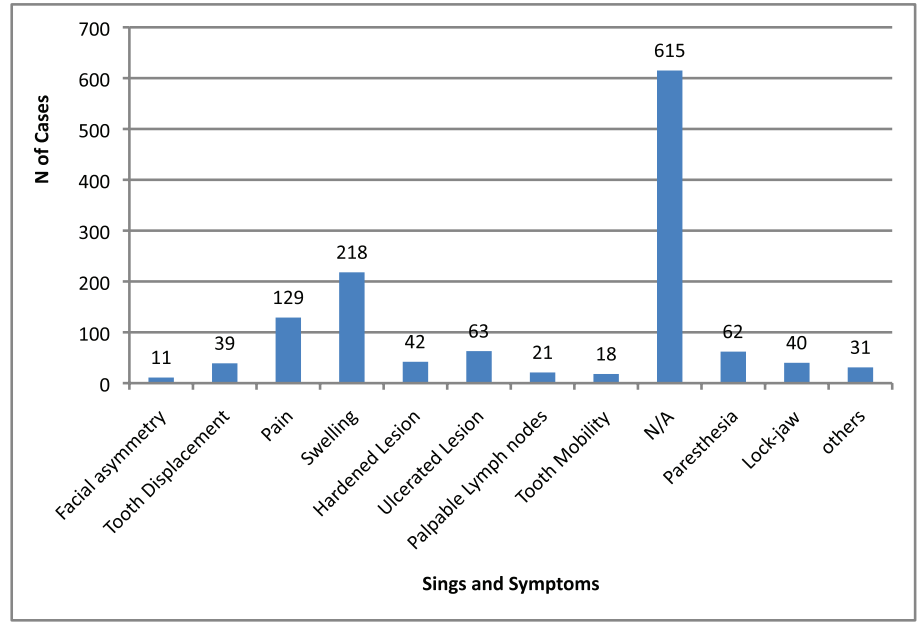

Figure 3. Signs and symptoms in head and neck region. Others = poor alveolar scarring, mandibular fracture, periodontal pocket, exposed bone, fistulas, bleeding, and macroglossia. N/A = not available.

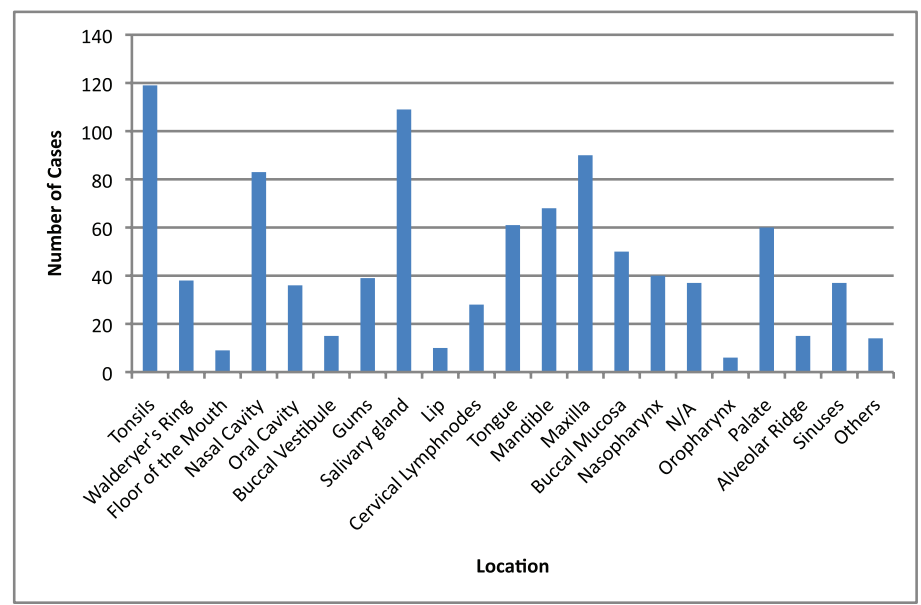

Figure 4. Location of lymphomas in head and neck region. Locations are listed as reported in the articles. N/A = not available; Others = lip commissure, zygomatic bone, masseter, and retromolar trigone. 


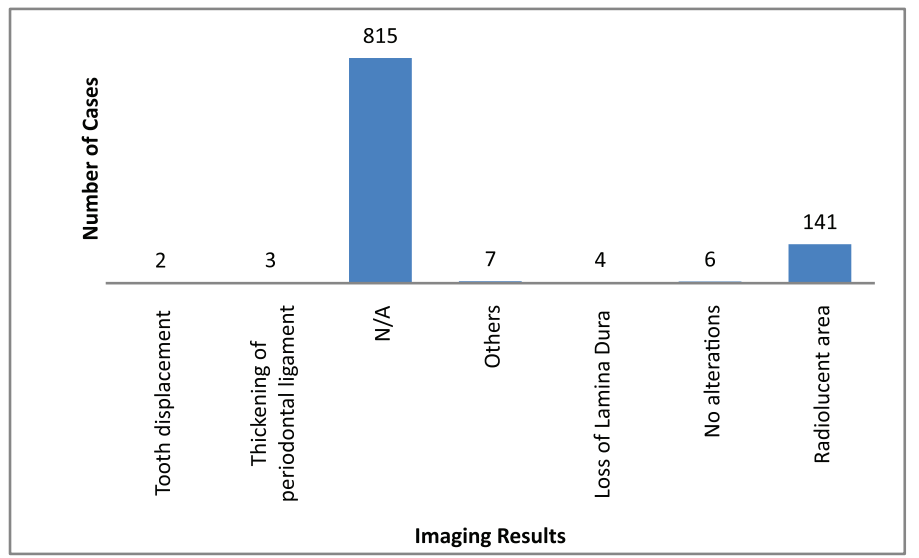

Figure 5. Imaging results. N/A = not available. Others = mandibular fracture, poor alveolar scarring, unclear image, image evoking invasive lesion, $6 \mathrm{~cm}$ increase, and infiltrative lesion.

\section{Discussion}

This systematic review includes the presentation of 982 cases reported in 73 scientific papers, including 76 patients described in case reports papers and 906 patients presented in retrospective studies (Table 1). The articles were generated over the last 45 years which is when most studies on the subject were published, according to our search. The articles identified revealed a shortage of studies addressing the oral manifestations of lymphoma. The few studies addressing the oral manifestations presented few details about the intraoral clinical manifestations of lymphoma or radiographic findings. This shortcoming may be because of the challenging nature of studying and treating such patients.

Imaging is important for diagnostic confirmation and for better estimating prognosis, since the oral manifestations of lymphoma can mimic various diseases. There were no imaging results available for 815 cases of lymphoma in the head and neck region. This lack of imaging results made it difficult to compare and discuss radiographic features.

Among the 163 cases with radiological findings, most showed radiolucent images representing bone resorption or bone loss. Radiographically, intraosseous lesions appear as radiolucent areas both uni- and multilocular with diffuse edges [2]. Therefore, the radiographic manifestation observed in most cases could be a differential diagnosis of various bone diseases.

Some authors presented thickening of the periodontal ligament space $[28,34,38,46$, and 70$]$ and loss of the lamina dura [28, 34, and 46] as radiographic findings. The loss of the lamina dura in lymphoma patients may not simply be related to the effects of tumour cell infiltration. In some cases the bone changes in lymphoma patients may be because of the release of osteoclast-activating factors from the lymphoid cells [34]. These radiographic features can mimic various periodontal diseases such as periodontitis, periodontal abscess, and PapillonLefèvre syndrome, among others. In addition, the bone destruction observed in clinically aggressive lymphomas is indistinguishable from that of other malignant tumours of the jaw, [2 and 26] which reinforces the importance of biopsy for proper diagnosis.

In this review, we observed that diffuse large B-cell non-Hodgkin's lymphoma (DLBCL) was the most common histological type of lymphoma in the head and neck region [2, 10, 53, 87-89]. Other authors add that it is the most common lymphoid malignancy among adults [90-93], representing $40 \%$ of lymphomas [2 and 94]. Extranodal DLBCL mostly affects older men in their seventh decade of life [80 and 95].

More than $90 \%$ of the AIDS-related NHL are B-cell origin. According to the WHO classification, two histological subtypes are dominant. DLBCL as the most frequent histological subtype, occurring in $70-80 \%$ of the cases and the Burkitt's lymphoma (BL) representing $7-20 \%$ of all cases [96]. Plasmablastic lymphoma (PBL) is described as an aggressive and rare DLBCL subtype, commonly found in patients infected with HIV. It represents $2.6 \%$ of all AIDS-related lymphomas [97]. The Epstein-Barr virus is strongly associated to the pathogenesis 
of the PBL. It is found on $60-80 \%$ of the DLBCL and $50 \%$ of the Burkitt's lymphoma [96]. The HHV-8 is another oncogenic virus that has been also related in association with PBL in patients with AIDS. The role of the HHV-8 on the pathogenesis of the PBL remains unclear but many authors have been reporting this fact. [98] The immunophenotype is similar to the myeloma because of the presence of plasma cell markers and the absence of B-cell markers [99].

PBL was originally described as a disease that involves the oral cavity of immunodeficient patients. Usually, it is associated with a poor prognosis and low survival rate after diagnosis, ranging from 4-11 months [99]. In the general population Waldeyer's ring is the most common site of NHL of head and neck region. The tonsils are the most prevalent localisation. The AIDS-related NHL of the head and neck often presents as a large mass with bone destruction of the maxilla and sinuses. Inside the oral cavity, this large mass usually involves the gums and hard palate presenting as ulcerative lesions [13].

Burkitt's lymphoma (BL) clinically occurs more often in children and is relatively rare in middle-aged or elderly adults [72]. Burkitt's lymphoma can be classified into three clinical subtypes: the endemic type (African) which involves the jaws in over $50 \%$ of cases, the sporadic type which generally presents an abdominal mass [67], and the type associated with acquired immunodeficiency [72]. Several studies strongly suggest the involvement of the Epstein-Barr virus (EBV) in BL pathogenesis, since EBV inhibits programmed cell death and contributes to the development and maintenance of $\mathrm{BL}$ [60]. In this systematic review, BL was more common in males, and the most affected areas of this type of lymphoma were the mandible followed by the maxilla. The main findings in the intraoral and extraoral examinations were swelling, pain, dental displacements, and facial asymmetry. Regarding imaging, the main findings were bone resorption, followed by lesions with diffuse boundaries. According to Freitas et al [60], males are affected about twice as much as females, which is in line with the findings in this systematic review. To the best of our knowledge, there has been no satisfactory explanation for the common involvement of the jaws [34]. In the oral cavity, this tumour can progress rapidly and present itself as an exophytic mass or a facial swelling involving the jaws [100]. The tumour usually begins in the posterior maxilla and then spreads to the four quadrants, resulting in increased tooth mobility, intraoral masses, lip numbness, and tooth pain because of infiltration in the pulp, especially by developing teeth. Radiographically, it appears as noise traces with radiolucent edges, while cortical bone is expanded, eroded, or perforated by infiltration of soft tissues [101].

According to Colmenero et al [87], intraoral lymphomas' first signs may appear as infection in $50 \%$ of the cases. Occasionally, oral manifestations may present as the first and only sign of disease [102], and dentists must provide the correct evaluation and proceed accordingly. Oral manifestations usually include asymptomatic soft swelling [26] with or without ulceration that primarily affect the tonsils, palate, buccal mucosa, gums, tongue, floor of the mouth, salivary glands, and retromolar region [102]. Alveolar bone loss with oedema and pain may also occur which often mimics periodontal diseases. This may lead to ineffective treatments with antibiotics and supra- and subgingival scaling as described in studies presented by Spatafore et al [38], Dood et al [40], and Nittayamanta et al [46], where incorrect treatment further delayed the onset of lymphoma treatment, worsening the prognosis. Authors such as Richards et al [26], Forman et al [28], Groot et al [39], Rosenberg et al [44], Freitas et al [60] and Santos et al [62] presented clinical cases in which extractions were conducted simply because there was tooth mobility and periodontal pockets, or because of previous unsuccessful periodontal treatment or pericoronaritis. Lip paresthesia and pathologic fractures may also occur, and are common signs of jaw involvement [90]. Some authors such as Wright et al [30], Cohen et al [32], Conteras et al [50], Farias et al [59], and Bombeccari et al [69] made an initial diagnosis of traumatic injury because of the presence of trauma prior to swelling presented at the time of clinical examination. This swelling caused these authors to opt for incisional biopsy in an effort to aid in appropriately beginning the treatment. Some patients may also have regional lymph node involvement [73], which in most cases is initially diagnosed as tonsillitis and treated with antibiotics, as noted in the study by Chicareli et al [71]. In many cases, intraoral clinical manifestations are similar to those of squamous cell carcinoma and the diagnosis can only be established through biopsy [26, 90]. As can be seen, the differential diagnosis of dental infections and benign or malignant lesions is essential for treatment.

\section{Conclusion}

Overall, lymphomas respond very well to chemotherapy and oral manifestations start regressing from the seventh day of treatment. Therefore, misdiagnosing and applying the wrong treatment, such as dental procedures, may end up delaying the correct diagnosis and worsening the prognosis. A good medical history, detailed clinical and imaging evaluations, and attention to the patient's signs and symptoms are crucial for the correct diagnosis and appropriate treatment, which in turn can lead to better patient prognosis. 


\section{References}

1. Mawardi H, Cutler $\mathrm{C}$ and Treister N (2009) Medical management update: Non-Hodgkin Lymphoma Oral Surg Oral Med Oral Pathol Oral Radiol Oral J Endod 107(1) 19-33 DOI: 10.1016/j.tripleo.2008.08.054

2. Kemp S et al (2008) Oral non-Hodgkin's lymphoma: review of the literature and World Health Organization classification with reference to 40 cases Oral surg Oral med Oral Pathol Oral Radiol Endod 105(2) 194-201 DOI: 10.1016/j.tripleo.2007.02.019

3. Inchingolo F et al (2011) Non-hodgkin lymphoma affecting the tongue: unusual intra-oral locatio Head Neck Oncol 3(1) 1-5 DOI: 10.1186/1758-3284-3-1

4. Weber AL, Rahemtullah A and Ferry JA (2003) Hodgkin and non-hodgkin lymphoma of the head ad neck: clinical, pathologic, and imaging evaluation Neuroimaging Clin Nh Am 371-92 DOI: 10.1016/S1052-5149(03)00039-X

5. Boulaadas M et al (2008) Primary extranodal non-Hodgkin's lymphoma of the oral cavit J Craniofac Surg 19(4) 1183-5 DOI: 10.1097/SCS.0b013e3181764b56 PMID: 18650758

6. Ugboko VI et al (2004) Orofacial non-Hodgkin's lymphoma in Nigerians J Oral Maxillofac Surg 62(11) 1347 DOI: 10.1016/j. joms.2004.07.003 PMID: 15510355

7. Zucca E et al (1999) Primary extranodal non-Hodgkin's lymphomas. Part 2: Head and neck, central nervous system and other less common sites Ann Oncol 10(9) 1023-33 DOI: 10.1023/A:1008313229892 PMID: 10572599

8. Ishimaru T et al (2005) Hodgkin's lymphoma of the mandibular condyle: report of a Case J Oral Maxillofac Surg 63(1) 144-7 DOI: 10.1016/j.joms.2004.06.050 PMID: 15635570

9. Wulfrank D et al (1987) Extranodal non-Hodgkin's lymphoma of the head and neck Radiother Oncol 8(3) 199-207 DOI: 10.1016/ S0167-8140(87)80243-8 PMID: $\underline{3575786}$

10. Epstein JB, Epstein JD and Le NDGorsky M (2001) Characteristics of oral and paraoral malignant lymphoma: a populationbased review of 361 cases Oral Surg Oral Med Oral Pathol Oral Radiol Endod 92(5) 519-25 DOI: 10.1067/moe.2001.116062 PMID: 11709688

11. Ferlay J et al (2013) GLOBOCAN 2012 v1.0, Cancer Incidence and Mortality Worldwide: IARC CancerBase No. 11 [Internet]. Lyon, France: International Agency for Research on Cancer; 2013 available from: http://globocan.iarc.fr, accessed on 11 March, 2015

12. Corti $\mathrm{M}$ et al (2015) An aggressive plasmablastic lymphoma of the oral Cavity as primary manifestation of acquired immunodeficiency syndrome: case report and literature review Int Arch Otorhinolaryngol 19 354-8 DOI: 10.1055/s-0034-1397335 PMID: 26491484 PMCID: $\underline{4593910}$

13. Corti M et al (2015) Primary Extranodal Non-hodgking Lymphoma of the Head and Neck in Patients with Acquired Immunodeficiency Syndrome: A clinicopathologic Study of 24 patients in a Single Hospital of Infectious Diseases in Argentina Int Arch Otorhinolaryngol 19(4) 354-8 PMID: 26491484 PMCID: 4593910

14. Pinisetti S et al (2013) HIV associated intra-oral Burkitt's lymphoma: a case report J Clin Diagn Res 7(12) 3088-9

15. Corti $\mathrm{M}$ et al (2010) Non-Hodgkin lymphomas of the oral cavity in AIDS patients in a reference hospital of infectious diseases in Argentina: report of eleven cases and review of the literature J Gastrointestinal Cancer 42(3) 143-8 DOI: 10.1007/s12029-0109173-9 PMID: 20563896

16. Jaffe ES et al (1999) World Health Organization classification of neoplasic diseases of the hematopoietic and lymphoid tissues. A progress report Am J Clin Pathol 111(1 Suppl 1):8-12

17. Harris NL, Jaffe ES and Stein H (1994) A revised European-American classification of lymphoid neoplasms: a proposal from the International Lymphoma Study Group Blood 84(5) 1361-92 PMID: $\underline{8068936}$ 
18. Greenleef RT et al (2000) Cancer statistics, 2000 CA Cancer J Clin 50(1) 7-33

19. Paes RAP et al (2002) Classificação da Organização Mundial de Saúde para as neoplasias os tecidos hematopoiético e linfóide: proposta de padronização terminológica em língua portuguesa do grupo de hematopatologia da Sociedade Brasileira de Patologia J Bras Patol Med Lab 38 237-9 DOI: 10.1590/S1676-24442002000300013

20. Bassi GS (2001) An unusual presentation of non-hodgkin's lymphoma in the head and neck Am J Clin Oncol 24(2) 131-4 DOI: 10.1097/00000421-200104000-00006 PMID: 11319285

21. Devita VT, Hellman S and Rosemberg SA (1997) Cancer: principles and practice of oncology $5^{\circ}$ edição New York: LippincottRaven 2 2165-220

22. Angiero F; Stefani M and Crippa AR (2006) Primary non-Hodgkin's lymphoma of the mandibular gingival with maxillary gingival recurrence Oral Oncology Extra 42123-8 DOI: 10.1016/j.00e.2005.10.008

23. Sasai $\mathrm{K}$ et al (2000) Head-and-neckstages II extranodal non-hodgkin and I lymphomas: real classification and selection for treatment modality Int J Radiat Oncol Biol Phys 48(1) 153-60 DOI: 10.1016/S0360-3016(00)00597-6 PMID: 10924985

24. Moret Y, Perez C and Rivera H (1999) Linfoma no Hodgkin de células grandes no hendidas de la cavidad bucal Acta Odontol Venez 37(3)

25. Levine AM (2000) AIDS-related lymphoma:clinical aspacts Semin Oncol 27(4) 442-53 PMID: 10950371

26. Richards A et al (2000) Oral mucosal non-hodgkin's lymphoma \pm a dangerous mimic Oral Oncology 36(6) 556-8 DOI: $10.1016 /$ S1368-8375(00)00047-6 PMID: 11036251

27. Moher D et al (2009) Preferred reporting items for systematic reviews and meta-analyses: the PRISMA statement PLoS Med 6(7) e1000097 DOI: 10.1371/journal.pmed.1000097 PMID: 19621072 PMCID: 2707599

28. Forman GH and Wesson CM(1970) Hodgkin's disease of the mandible Br J Oral Surg 7(3) 7 146-52

29. Harman M et al (1978) Mycosis fungoides with involvement of the oral cavity. JAMA Otolaryngology - Head \& Neck Surgery, v. 93, n.3, 1971Laskaris GC, Nicolis GD, Capetanakis JP. Mycosis fungoides with oral manifestations Oral Surgery Oral Medicine Oral Pathol 46(1) 40-2

30. Wright JM Jr, Balciunas BA and Muus JH (1981) Mycosisfungoides with oral manifestations report of a case and review of the literature Oral Surg Oral Med Oral Pathol 51(1) 24-31 DOI: 10.1016/0030-4220(81)90122-5 PMID: 7007952

31. Horiuchi $\mathrm{J}$ et al (1982) Extranodal non-hodgkin's lymphomas in the head and the neck: irradiation and clinical course Acta Radiologica Oncology 21(6) 393-9 DOI: 10.3109/02841868209134318

32. Cohen MA et al (1984) Hodgkin's disease of the jaws Oral Surg 57(4) 413-7 DOI: 10.1016/0030-4220(84)90161-0 PMID: 6584838

33. Barker GR (1984) Unifocal lymphomas of the oral cavity Br J Oral Maxillofac Surg 22(6) 426-30 DOI: 10.1016/0266-4356(84)90049-4 PMID: $\underline{6239645}$

34. EisenbudLMir R, Sciubba J and Sachs SA (1985) Oral presentations in non-Hodgkin's lymphoma: a review of thirty-one cases Oral Surg Oral Med Oral Pathol 59(1) 44-51 DOI: 10.1016/0030-4220(85)90114-8

35. Evans GE and Dalziel KL (1987) Mycosis fungoides with oral involvement: a case report and literature review Int J Oral Maxillofacial Surgery 16(5) 634-37 DOI: 10.1016/S0901-5027(87)80120-0

36. Kaugars GE, Burns JC and Va R (1989) Non-hodgkin's lymphoma of the oral cavity associated with AIDS Oral Surg Oral Med Oral Pathol 67(4) 433-6 DOI: 10.1016/0030-4220(89)90387-3 PMID: 2786177

37. Soderholm AL et al (1990) Non-hodgkin's lymphomas presenting through oral symptoms Int J Oral Maxillofac Surg 19(3) 131-4 DOI: 10.1016/S0901-5027(05)80126-2 PMID: 2114452 
38. Spatafore CM, Keyes G and Skidmore AE (1989) Lymphoma: an unusual oral presentation J Endod 15(9) 438-41 DOI: $10.1016 /$ S0099-2399(89)80179-7 PMID: 2637338

39. Groot RH, Merkesteyn JPR and Bras J Oral manifestations of non-hodgkin's lymphoma in HIV-infected patients Int J Oral Maxillofac Surgery 19(4) 194-6

40. Dodd CL et al (1992) Unusual oral presentation of non-hodgkin's lymphoma in association with HIV infection Oral Surg Oral Med Oral Pathol 73(5) 603-8 DOI: 10.1016/0030-4220(92)90107-2 PMID: 1518649

41. Sirois D et al (1993) Oral manifestations of cutaneous T-cell lymphoma a report of eight cases Oral Surg Oral Med Oral Pathol 75(6) 700-5 DOI: 10.1016/0030-4220(93)90426-5 PMID: 8515982

42. Scully $C$ et al (1993) Oral presentation of lymphoma: case report of T-cell lymphoma masquerading as oral crohn's disease, and review of the literature Oral Oncol Eur J Cancer 29B(3) 225-9 DOI: 10.1016/0964-1955(93)90027-C

43. Piluso $S$ et al (1994) Unusual clinical aspects of oral non-hodgkin lymphomas in patients with hiv infection Oral Oncol Eur $J$ Cancer 30B (1) 61-4 DOI: 10.1016/0964-1955(94)90053-1

44. Rosenberg A et al (1996) Primary extranodal CD 30-positive T-cell non-hodgkin's lymphoma of the oral mucosa Int J Oral and Maxillifac Surgery 25(1) 57-9 DOI: 10.1016/S0901-5027(96)80013-0

45. Shindoh $\mathrm{M}$ et al (1997) Comparison between submucosal (extra-nodal) and nodal non-Hodgkin's lymphoma (NHL) in the oral and maxillofacial region J Oral Pathol Med 26(6) 283-9 DOI: 10.1111/j.1600-0714.1997.tb01238.x PMID: $\underline{9234189}$

46. Nittayananta $W$ et al (1998) Burkitt-like lymphoma presenting as a periodontal disease in AIDS patients: a report of two cases Oral Diseases 4(4) 281-4 DOI: 10.1111/j.1601-0825.1998.tb00293.x

47. Savarrio $L$ et al (1999) Spontaneous regression of an anaplastic large cell lymphoma in the oral cavity: first reported case and review of the literature Oral Oncology 35(6) 609-13 DOI: 10.1016/S1368-8375(99)00034-2

48. Cohn AM et al (1971) Mycosis fungoides with involvement of the oral cavity Arch Otolaryngol 93(3) DOI: 10.1001/ archotol.1971.00770060468019 PMID: $\underline{542358}$

49. Gomez-de la Fuente EG et al (2000) Oral involvement in mycosis fungoides: report of two cases and a literature review Acta Derm Venereol 80(4) 299-301 DOI: 10.1080/000155500750012234

50. Jaehne $\mathrm{M}$ et al (2001) The clinical presetation of non-hodgkinlymhpomas of the major salivary glands Acta Oto-laryngologica 121(5) 647-51 DOI: 10.1080/000164801316878980 PMID: 11583402

51. Conteras E et al (2001) Linfoma no-hodgkin intraoral.presentación de 4 casos clínicos Acta Otorrinolaringol Esp 52(7) 609-14 DOI: $10.1016 /$ S0001-6519(01)78255-6

52. Nalli G et al (2003) Manifestaciones gingivales del linfoma B en la cavidad bucal, diagnóstico diferencial Cátedra de Clínica Estomatológica Facultad de Odontología. Universidad de Buenos Aires

53. Wain EM et al (2003) Mycosis fungoides involving the oral mucosa in a child Clin Exp Dermatol 28(5) 499-01 DOI: 10.1046/j.13652230.2003.01348.x PMID: 12950337

54. Van der waal RI et al (2004) Characteristics of $\mathbf{4 0}$ primary extranodal non-hodgkin lymphomas of the oral cavity in perspective of the new who classification and the international prognostic index Int J Oral Maxillofac Surg 34(4) 391-5 DOI: 10.1016/j. ijom.2004.08.009

55. Radhakrishnan R (2005) Plasmablastic lymphoma of the oral cavity in HIV-positive child Oral Surg Oral Med Oral Pathol Oral Radion Endod 100(6) 725-31 DOI: 10.1016/j.tripleo.2005.03.028

56. Albuquerque MA et al (2005) Adult T-cell leukemia/lymphoma with predominant bone involvement, initially diagnosed by its oral manifestation: a case report Oral Surg Oral Med Oral Pathol Oral Radion Endod 100(3) 315-20 DOI: 10.1016/j.tripleo.2005.03.039 
57. Kojima $\mathrm{M}$ et al (2006) Marginal zone B-cell lymphoma of minor salivary gland representing tumor-forming amyloidosis of the oral cavity. A case report J Oral Pathology \& Medicine 35(5) 314-16 DOI: 10.1111/j.1600-0714.2006.00408.x

58. Otmani N and Khattab M (2007) Oral Burkitt's lymphoma in children: the Moroccan experience Int J Oral and Maxillofacial Surgery 37(1) 36-40 DOI: 10.1016/j.ijom.2007.06.010

59. Jham BC et al (2007) Primary diffuse large B-cell lymphoma of the oral cavity J Bras Patol Med Lab 43(5) 369-72 DOI: 10.1590/ $\underline{\text { S1676-24442007000500010 }}$

60. Farias JG et al (2008) Linfoma não-hodgkin de células B: relato de caso Rev Cir TraumatolBuco-Maxilo-fac 8(3) 25-30

61. Freitas RA, Barros SSLV and Quinderé LB (2008) Linfoma de Burkitt oral: relato de caso Rev Bras Otorrinolaringol 74(3) 458-61 DOI: $10.1590 / S 0034-72992008000300023$

62. Keszler A et al (2009) Extranodal oral non-Hodgkin's lymphomas. A restropective study $\mathbf{4 0}$ cases in Argentina. Acta Odontol Latinoam, v. 21, n. 1, p. 43-8, 2008.De-Misa RF, García M, Dorta S, Febles C, Hernández-Machín B, Serrano S, et al. Solitary oral ulceration as the first appearance of lymphomatoid papulosis: a diagnostic challenge Clin Exp Dermatol 35 165-8

63. Santos PSS et al (2009) Manifestação bucal de linfoma difuso de grandes células B Rev Bras Hematol Hemoter DOI: $10.1590 /$ $\underline{\mathrm{S} 1516-84842009005000079}$

64. Villa A, Mariani U and Villa F (2010) T-cell lymphoma of the oral cavity: a case report Aust Dent J 55(2) 203-6 DOI: 10.1111/j.18347819.2010.01212.x PMID: $\underline{20604765}$

65. Bégon E et al (2010) Oral manifestation of T-cell leukemia/lymphoma Arch Dermatol 146(7) 804-5 DOI: 10.1001/archdermatol.2010.146 PMID: 20644053

66. Bortoluzzi MC et al (2010) Diffuse large B-cell lymphoma of the oral cavity Revista Cubana de Estomatología 47(3) 341-6

67. Rao DD et al (2010) Plasmablastic lymphoma of the oral cavity in immunocompetent patients: report of two cases Int $J$ Oral Maxillofac Surgery 39(10) 1036-9 DOI: 10.1016/j.ijom.2010.04.040

68. Pereira CM et al (2010) Burkitt's lymphoma: clinic progression and prognosis. Two different cases reports in young patients Rev Odonto Ciênc 25(4) 417-21

69. Bulut E et al (2011) Diffuse large B-cell lymphoma with oral manifestations J Craniofacial Surg 22(3) 1144-7 DOI: 10.1097/ SCS.0b013e318210b940

70. BombeccariGP et al (2011) Mucosa-associated lymphatic tissue lymphoma of the lower lip in a child J Pediatric Surg 46(12) 2414-6 DOI: $10.1016 / \mathrm{j} . j p e d s u r g .2011 .09 .055$

71. Chi AC et al (2012) Spindle cell lymphoma of the oral cavity: a case report and review of the literature J Oral Maxillofac Surg 70 2229-37 DOI: 10.1016/j.joms.2011.09.026 PMID: 22209098

72. Chicarelli $\mathrm{M}$ et al (2012) Linfoma no hodgkin de células de manto: relato de caso raro y la presentación a los profesionales de la salud de la importancia de un diagnostico precoz Acta Odontológica Venezolana 51(1)

73. Kikuchi K et al (2012) Adult sporadic Burkitt lymphoma of the oral cavity: a case report and literature review J Oral Maxillofac Surg 70(12) 2936-43 DOI: 10.1016/j.joms.2012.02.017 PMID: 22520562

74. Triantafillidou $\mathrm{K}$ et al (2012) Extranodal non-hodgkin lymphomas of the oral cavity and maxillofacial region: a clinical study of 58 cases and review of the literature $J$ Oral Maxillofac Surg 70(12) 2776-85 DOI: 10.1016/j.joms.2012.01.018 PMID: 22494508

75. Fortuna $\mathrm{G}$ et al (2013) Oral plasmablastic lymphoma in an HIV-positive patient with an unusual survival rate Infection 41(1) 301-2 DOI: $\underline{10.1007 / s 15010-012-0270-5}$ 
76. Gabali A et al (2013) Pediatric extranodal marginal zone B-cell lymphoma presenting as amyloidosis in minor salivary glands: a case report and review of the literature J Pediatric Hmatol Oncol 35(3) 130-3 DOI: 10.1097/MPH.0b013e3182826656

77. Ferreira CMSD et al (2013) Linfoma não-hodgkin de células t envolvendo a cavidade oral em paciente com o vírus da imunodeiciência humana positivo Relato de caso Rev Bras Clin Med 11(3) 300-2

78. Pinisetti S et al (2013) HIV associated intra-oral Burkitt's lymphoma: a case report J Clin Diag Res 7(12) 3088-9

79. Shwetha V et al (2014) Primary extranodal lymphomas of lip - A rare manifestation in Sjogren's syndrome J Clin Diag Res 8(3) 272-4

80. Medel $\mathrm{N}$ and Hamao-Sakamoto A A case of oral plasmablastic lymphoma and review of current trends in oral manifestations associated with human immunodeficiency virus infection J Oral Maxillofac Surg 72(9) 1729-35 PMID: 25043145

81. Cozzolino I et al (2014). Fine needle aspiration cytology of lymphoproliferative lesions of the oral cavity Cytopathology 25(4) 241-9 DOI: 10.1111/cyt.12132 PMID: 24750323

82. Ramanathan A et al (2014) Oral extranodal non Hodgkin's lymphoma: series of forty two cases in Malaysia .Asian Pac J Cancer Prev 15(4) 1633-7 DOI: 10.7314/APJCP.2014.15.4.1633 PMID: 24641380

83. Owosho AA et al (2014) Large B-cell lymphoma of the base of the tongue and oral cavity: a practical approach to identifying prognostically important subtypes Oral Surg Oral Med Oral Pathol Oral Radio 118(3) 338-47 DOI: 10.1016/j.0000.2014.06.002

84. Cuestas G et al (2015) Palatine tonsil lymphoma in children with tonsillar asymmetry. case report. Arch Argent Pediatr 113(4):e219-e222 PMID: 26172022

85. Samoon Z et al (2015) Plasmablastic lymphoma of the oral cavity with breast recurrence: a case report BMC Res Notes 8180 DOI: 10.1186/s13104-015-1132-x PMID: 25933603 PMCID: 4429835

86. Philipone E, Bhagat $\mathrm{G}$ and Alobeid B (2015) Oral cavity lymphoid neoplasms. A fifteen-year single institution review $N$ Y State Dent J 81(3) 44-7 PMID: 26094364

87. Colmenero C et al (1991) AIDS-related lymphoma of the oral cavity Int J Oral Maxillofac Surg 20(1) 2-6. DOI: 10.1016/S09015027(05)80684-8 PMID: 2019778

88. Fukuda $\mathrm{Y}$ et al (1897) Malignant Lymphoma of the oral cavity clinicophatologic analysis of 20 cases J Oral Pathol 16(1) 8-12 DOI: $10.1111 / \mathrm{j} .1600-0714.1987 . t b 00669 . x$

89. Slootweg PJ et al (1985) Extranodal non-Hodgkin's lymphoma of the oral tissues: An analysis of 20 cases $J$ Maxillofac Surg 13(2) 85-92 DOI: $\underline{10.1016 / S 0301-0503(85) 80022-9}$ PMID: $\underline{3858400}$

90. Solomides CC et al (2002) Lymphomas of the oral cavity: histology immunologic type, and incidence of Epstein-Barr virus infection Hum Pathol 33(2) 153-7 DOI: 10.1053/hupa.2002.30721 PMID: 11957138

91. Rosai J (2004) Rosai and Ackerman's Surgical Pathology. $9^{\text {th }}$ ed Vol II. St Louis, MO: Mosby

92. Mills SE (2004) Sternberg's diagnostic Surgical Pathology,4 ${ }^{\text {th }}$ ed. Vol I Philadelphia, PA: Lippincott Williams \& Wilkins 2004

93. Jaffe ES et al (2001) World Health Organization Classification of tumours. Pathology and Genetics Tumours of Haematopoietic and lymphoid Tissues Lyon, France: IARC Pres, 2001

94. Simonitsch-Klupp I et al (2004) Diffuse large B-cell lymphomas with plsmablastic/ plasmacytoid features are associated with TP53\# deletions and poor clinical outcome Leukemia 18(1) 146-55 DOI: 10.1038/sj.leu.2403206

95. Zapater E et al (2010) Malignant Lymphoma of the herad and neck Oral Dis 16(2) 119-28 DOI: 10.1111/j.1601-0825.2009.01586.X PMID: 20374502 
96. Moller MB, Pedersen NT and Christensen BE (2004) Diffuse large B-Cell lymphoma: clinical implications of extranodal versus nodal presentation-A population-based study of 1575 cases Br J Haematol 124(2) 151-9 DOI: 10.1046/j.1365-2141.2003.04749.x

97. Corti M et al (2013) Linfoma de Burkitt primario de la cavidad oral en una paciente con sida. Reporte de un caso y revisión de la literatura Rev Esp Cir Oral Maxilofac

98. Corti M et al (2015) Plasmablastic lymphoma of the oral cavity: an aggressive subtype of lymphoma strongly associated with the human immunodeficiency virus infection $J J$ Otolaryn 1 1-5

99. Corti $\mathrm{M}$ et al (2011) Oral cavity and extra-oral plasmablastic lymphomas in AIDS patients: report of five cases and review of the literature Int J STD AIDS 22(12) 759-63 DOI: 10.1258/ijsa.2011.011235 PMID: 22174064

100. Chihuam GG et al (2014) Plasmablastic lymphoma: a case of rectal disease with boné marrown involvement in a HIV positive patient Ver Gastroenreol Peru 34(4) 347-50

101. Takahashi $\mathrm{H}$ et al (1992) Primary malignant lymphoma of the salivary glands: a tumor of mucosa- associated lymphoid tissue J Oral Pathol Med 21(7) 318-25 DOI: 10.1111/j.1600-0714.1992.tb01019.x PMID: 1522534

102. Ardekian L et al (1999) Burkitt's Lymphoma oh the oral cavity in Israel J Cranio-MaxillofacSurg 27(5) 294-7 DOI: 10.1054/ jcms.1999.0074

103. Adeyemo WL et al (2011) Orofacial manifestation of hematological disorders: Hemato-oncologic and immune-deficiency disorders Indian J Dent Res 22(5) 88-97 